\title{
Pengaruh Model Learning Cycle 5E Berbantuan Mind map Terhadap Pengetahuan Faktual Dan Konseptual Pada Pembelajaran IPA Siswa Kelas V Sekolah Dasar
}

\author{
Isna Fiky Nalansari \\ Universitas Bengkulu \\ nalansaribkl17@gmail.com \\ Endang Widi Winarni \\ Universitas bengkulu \\ endangwidiw@gmail.com \\ Neza Agusdianita \\ Universitas Bengkulu \\ nezaagusdianita@unib.ac.id
}

\begin{abstract}
Abstrack
This study aims to determine the effect of the use of the Learning cycle $5 \mathrm{E}$ assisted by Mind map on the factual and conceptual knowledge of grade $V$ elementary school students on the learning of science. This type of research is quantitative research. The research method used was quasi experimental with the type of matching the pretest-posttest control group design. The population in this study was elementary school XIX Bengkulu City. The sampling technique uses cluster random sampling. The sample in this study is the VA class SDN 69 Bengkulu City totaling 30 students as the experimental class and the VB class SDN 72 Bengkulu City totaling 25 students as the control class. The research instrument used in this study was in the form of mind map quality assessment sheets and factual and conceptual knowledge assessment test sheets in the form of multiple choice given at the pre-test and post-test. The data analysis technique in this research is quantitative analysis using descriptive statistics and inferential statistics, the $t$-test. The research data obtained tcount $>$ ttable, namely factual knowledge 2.31> 2.01 and conceptual knowledge 3.30> 2.01. Thus it can be concluded that there is an influence of the use of the $5 E$ Learning cycle model with a mind map to the factual and conceptual knowledge of students in the learning of science class Vin elementary school.
\end{abstract}

Keywords: 5E Learning cycle, Mind map, Science Learning, Factual and Conceptual

\section{PENDAHULUAN}

Pembelajaran IPA di SD merupakan pembelajaran tentang pengetahuanpengetahuan alam yang ada dilingkungan sekitar peserta didik Sehingga diiharapkan siswa dapat mengenal dan mengetahui pengetahuan-pengetahuan alam 
tersebut yang berkaitan dengan kehidupan sehari-hari. Pembelajaran IPA di SD merupakan pondasi awal dalam menciptakan siswa-siswa yang memiliki pengetahuan, ketrampilan, dan sikap ilmiah. Menurut Winarni (2018a:13) Pada hakikatnya, IPA terdiri dari empat komponen yaitu sikap, proses, produk, dan aplikasi. Keempat komponen itu merupakan kesatuan yang tidak dapat dipisahkan dalam proses pembelajaran dan semua yang terkait dengan IPA.

Berdasarkan tuntutan pembelajaran IPA di SD tuntutan standar lulusan kompetensi yang tertuang dalam kompetensi inti pada Permendikbud No. 24 Tahun 2016 tentang Kompetensi Inti dan Kompetensi Dasar. Salah satu kompetensi inti sekolah dasar kelas 5 yaitu KI.3 memahami pengetahuan faktual dan konseptual dengan cara mengamati, menanya, dan mencoba berdasarkan rasa ingin tahu tentang dirinya, makhluk ciptaan Tuhan dan kegiatannya, dan benda-benda yang dijumpainya di rumah, di sekolah, dan tempat bermain. Secara khusus Kompetensi Dasar 3.6 yaitu menerapkan konsep perpindahan kalor dalam kehidupan seharihari, dimana siswa dituntut mampu memahami definisi, contoh maupun manfaat perpindahan kalor. Perpindahan kalor merupakan peristiwa yang cukup sering dialami maupun diamati oleh siswa sebagai pengetahuan faktual.

Dalam proses pembelajaran, siswa perlu difasilitasi membaca dan mengamati gejala-gejala fakta-fakta peristiwa yang terjadi di lingkungan. Faktayang telah didapat akan dibangun menjadi sebuah konsep yang teoritis. Selain itu, siswa perlu dilibatkan untuk menemukan fakta-fakta maupun konsep untuk kemudian diberi kesempatan menggali lebih dalam pengetahuan yang dimilikinya untuk kemudian dikembangkan. Salah satu alternative agar tercapainya pembelajaran tersebut yaitu dengan menggunakan model pembelajaran Learning cycle $5 \mathrm{E}$ yang berbasis konstruktivisme. Model siklus belajar memberi kesempatan siswa mengkonstruksi pengetahuannya melalui proses siswa terlibat, menggali sesuatu, menjelaskan secara mandiri, mengembangkan, dan berhasil dalam evaluasi.

Menurut Maulana (2015:62) Learning cycle patut dikedepankan karena sesuai dengan teori belajar piaget, konstruktivisme salah satunya adalah dalam pembelajaran perlu adanya investigasi dan penemuan yang merupakan pemecahan masalah. Berdasarkan hal itu, siswa secara individu akan terdidik untuk mengembangkan pemikirannya karena adanya waktu berpikir dan dapat menyempurnakan konsepsinya melalui kegiatan diskusi di kelas, memberikan kemudahan bagi siswa dalam memahami suatu konsep yang diajarkan dan siswa dapat lebih aktif dalam proses pembelajaran. Proses pembentukan pengetahuan akan lebih mudah karena siswa terlibat langsung dalam proses pembelajaran melalui kegiatan bertanya dan diskusi kelompok yang terdapat dalam tahapan Learning cycle 5E.

Model siklus belajar (Learning cycle 5E) memiliki kelemahan, yaitu memerlukan waktu yang panjang dalam melaksanakan pembelajaran dan guru kurang dapat menemukan miskonsepsi siswa khususnya fase engagement. Hal ini sesuai menurut Shoimin (2018:) salah satu kelemahan model pembelajaran learning cycle $5 \mathrm{E}$ yaitu memerlukan waktu dan tenaga yang lebih banyak dalam melaksanakan pembelajaran tersebut karena model siklus belajar terdiri atas beberapa tahapan dan menuntut siswa untuk memecahkan masalah serta mengkonstruksi pengetahuan sendiri, namun siswa kurang memiliki kesiapan untuk mengikuti proses pembelajaran di kelas. Akibatnya, waktu pembelajaran banyak terbuang pada fase eksplorasi dan fase eksplanasi.

Berdasarkan kelemahan pada model Learning cycle 5E, maka peneliti akan menggunakan peta pikir (mind map). Mind map dipilih karena dapat membantu siswa dalam menemukan konsep melalui aplikasi warna, bentuk, dan garis yang menarik sehingga materi lebih mudah dipahami. Hal ini sejalan dengan hasil 
penelitian Siswati (2015:135) bahwa efek penggunaan kata kunci, gambar dan warna akan membuat siswa lebih tertarik dan dapat mengingat materi pelajaran. Berdasarkan uraian diatas, menunjukkan bahwa dengan bantuan peta pikiran (mind map) model learning cycle 5E lebih efektif dalam meningkatkan pemahaman faktual maupun konseptual. Pada tahap pembangkitan minat (Engagement), guru memperlihatkan mind map yang sudah dipersiapkan sebelumnya, dimana dalam mind map terdapat ringkasan materi yang akan dipelajari dan terdapat gambargambar yang mempercantik tampilan mind map terebut dengan terlihat menarik, maka siswa akan tertarik untuk membuat mind map. Mind map juga dapat digunakan pada tahap elaboration untuk memperluas konsep yang didapatkan, sehingga apa yang mereka pelajari dan pahami sebelumnya dapat terkonsep dengan baik . Pemaduan teknik Mind map pada Learning cycle 5E selama kegiatan pembelajaran akan dapat membantu siswa untuk terlibat aktif dalam berpikir pada setiap tahapannya Mind map dapat membantu siswa dalam kegiatan merencanakan, mengkomunikasi, menyelesaikan masalah, dan mengevaluasi secara keseluruhan. Siswa yang terlibat aktif secara langsung dengan objek yang dipelajari menyebabkan pengetahuan dan pemahaman yang diperoleh siswa lebih bermakna.

Berdasarkan pemaparan di atas, maka penulis tertarik untuk melakukan penelitian tentang 1) Mengetahui kualitas mind map sebagai bantuan learning cycle $5 \mathrm{E}, 2)$ Pengaruh model learning cycle $5 \mathrm{e}$ berbantuan mind map terhadap pengetahuan faktual Siswa Pada Pembelajaran IPA Kelas V Sekolah Dasar, 3) Pengaruh model learning cycle 5e berbantuan mind map terhadap pengetahuan Konseptual Siswa Pada Pembelajaran IPA Kelas V Sekolah Dasar.

\section{METODE}

Jenis penelitian ini merupakan penelitian kuantitatif, termasuk dalam desain eksperimen semu atau disebut dengan quasy eksperimental design . quasy eksperimental mempunyai dua kelompok yaitu kelompok kontrol dan kelompok eksperimen. Penelitian ini dilakukan untuk pengaruh kualitas mind map yang dbuat siswa dan pengaruh model pembelajaran Learnng cycle 5E berbantuan Mind map terhadap pengetahuan faktual dan konseptual siswa pada pembelajaran IPA kelas V Sekolah dasar. Kelompk eksperimen akan diberikan perlakuan berupa pembelajaran menggunakan model learning cycle $5 \mathrm{E}$ berbantuan mind map. Sedangkan kelas kontrol menggunakan pembelajaran EEK standar proses. Desain penelitian yang digunakan yaitu the matching only pretest-postest group. Upaya matcing yang dilakukan yaitu pada materi pembelajaran, peneliti sebagai guru, uji homogenitas sampel dan soal pretest dan posttest.

Dalam penelitian ini yang menajdi populasi yaitu SD Gugus IX terdiri dari 6 SD. Penentuan sampe menggunakan cluster random sampling. Sampel dalam penelitian ini dipilih berdasarkan status sekolah negeri yang termask dalam gugus XIX, siswa kelas V, akreditasi A, dan menggunakan kurikulum 2013. Penentuan sekolah dipilih secara random dengan cara pengundian,sedangkan penentuan rombongan belajar ditentukan oleh sekolah. Sampel terpilih yaitu kelas V SD negeri 69 Kota Bengkulu berjumlah 30 orang sebagai kelas eksperimen dan SD negeri 72 Kota Bengkulu berjumlah 25 siswa sebagai kelas kontrol.

Instrumen yang digunakan dalam penelitian ini meliputi (1) lembar penilaian kualitas mind map (2) lembar penilaian pengetahuan faktual dan konseptual. Sebelum uji coba instrument terlebih dahulu dilakukan validasi oleh ahli salah satu dosen S2 Pendidikan dasar FKIP UNIB selaku dosen pakar IPA fisika, kemudian di lakukan validasi kembali oleh dosen pakar pendidikan IPA dan guru SDN 05 selaku validator perangkat pembelajaran. Berdasarkan hasil uji coba 
instrumen, diperoleh 23 soal valid dengan reliabel $r_{11}=0,916$. Dengan demikian semua butir soal layak digunakan untuk sebagai soal pretest dan posttest pada kelas eksperimen dan kelas kontrol.

Tes yang digunakan dalam pengambilan dan pengumpulan data yaitu tes pengetahuan faktual dan tes pengetahuan konseptual dengan jenis instrument tertulis (paper and pencil test) yaitu berupa tes pilihan ganda dalam bentuk (soal pre-test sama dengan post-test). Analisis data yang dilakukan meliputi analisis statistic deskriptif yaitu penyajian data melalui tabel, penghitungan skor rata-rata (mean), dan varian. Analisis uji prasyarat yaitu dengan uji normalitas dan uji homogenitas dan analisis inferensial yaitu uji-t.

\section{HASIL}

\section{Karya Mind map}

Hasil karya mind map, terdapat nilai yang berbeda-beda pada setiap hasil karya mind map. Skor tertinggi yang diperoleh siswa yaitu 10 (skor maksimal 12) dengan nilai 83,33 (rentang 1-100) terlihat pada gambar 1. Nilai terendah 5 dengan nilai 41,66 (rentang 1-100) terlihat pada gambar 2. dan rata-rata sebesar 63,681. Pada pelaksanaanya, karya mind map pada tahap engagement terbilang masih sederhana karena hanya menggunakan 1 kata kunci dan tambahan 1 cabang dari cabang utama dengan kata kunci tanpa penjelasan.

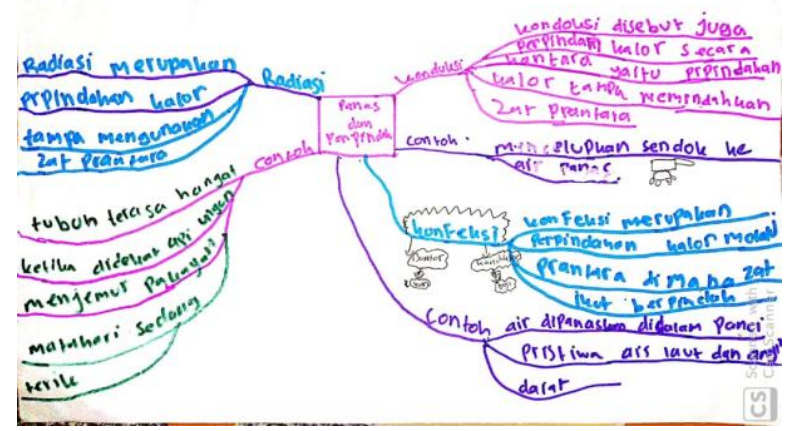

Gambar 1. Mind map siswa nilai tertinggi

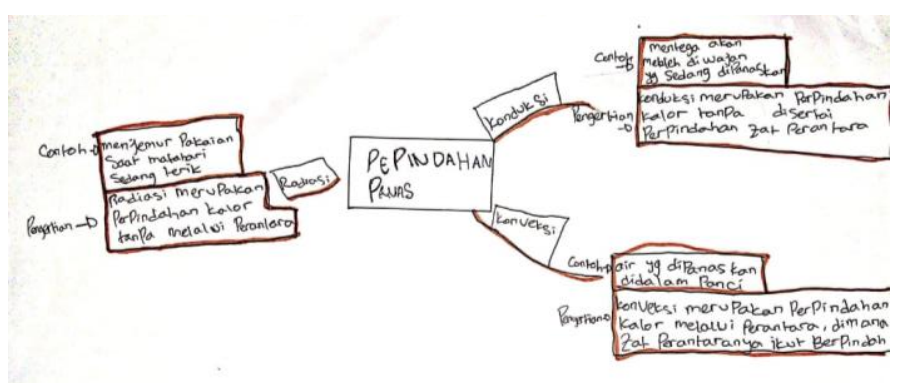

Gambar 2. Mind map siswa nilai terendah 


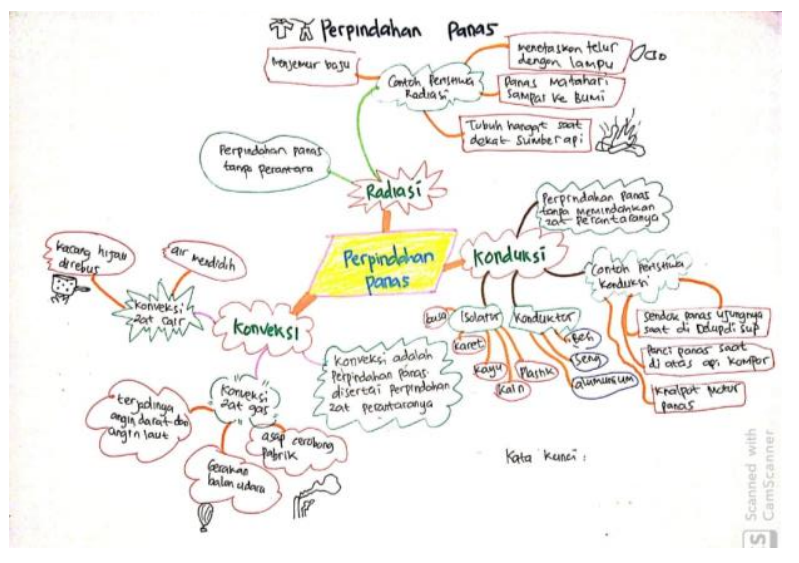

Gambar 3. Mind map buatan guru

\section{Pengetahuan Faktual}

Berdasarkan hasil analisis data, diperoleh nilai rata-rata posttest pengetahuan faktual pada pembelajaran IPA dikelas eksperimen yaitu 90, sedangkan pada kelas kontrol nilai pengetahuan faktual 90. Setelah melakukan perhitungan rata-rata, selanjutnya dilakukan uji normalitas. Pengujian normalitas menggunakan rumus chi-kuadrat. Diperoleh nilai xahitungkelas eksperimen pengetahuan faktual sebesar 10,97, pada kelas kontrol menunjukkan bahwa nilai $\mathrm{x}_{2}$ hitung pada pre-test pengetahuan faktual sebesar 2,6, dengan xatabel sebesar 11,07 artinya $\mathrm{x}_{2}$ hitung $<\mathrm{x}_{2}$ tabel. Hasil tersebut memberikan indikasi bahwa hasil pretest kelas eksperimen dan kelas kontrol berdistribusi normal. Hasil pretest menunjukkan bahwa nilai Fhitung pengetahuan faktual sebesar 1,70 dengan Ftabel sebesar 1,95 artinya status varian pretest kelas eksperimen dan kelas kontrol berasal dari varian yang homogen. Karena kedua sampel berdistribusi normal dan homogen, maka pengujian selanjutnya yaitu uji hipotesis dengan uji-t. hasil uji-t menunjukkanbahwa nilai thitung pengetahuan faktual sebesar 0,34 lebih kecil daripada ttabel sebesar 2,01 . Sehingga dapat disimpulkan bahwa tidak terdapat pengaruh untuk siswa antara kelas eksperimen dan kelas kontrol.

Selanjutnya dilakukan analisis data posttest, hasil posttest menunjukkan nilai rata-rata pada kelas eksperimen lebih besar daripada kelas kontrol yaitu 84,46 dan 73,59. Selanjutnya dilakukan uji normalitas chi-kuadrat, kelas eksperimen diperoleh x 2 hitung pengetahuan faktual sebesar 5,54 dan kelas kontrol 3,08. x2tabel adalah sebesar 11,07, artinya $\mathrm{x}_{2}$ hitung $<\mathrm{x}_{2}$ tabel. Hasil tersebut memberikan indikasi bahwa posttest kelas eksperimen dan kelas kontrol berdistribusi normal. Setelah melakuka uji normalitas, selanjutnya dilakukan uji homogenitas menggunakan uji F. Sampel dikatakan memiliki varian homogen apabila $\mathrm{F}_{\text {hitung }}<\mathrm{F}_{\text {tabel. }} \mathrm{F}_{\text {hitung }}$ posttest pengetahuan faktual sebesar 1,79, lebih besar dari $\mathrm{F}_{\text {tabel }}$ yaitu 2,01. Artinya status varian hasil posttest kelas eksperimen dan kelas kontrol berasal dari varian yang homogen. Karena kedua sampel berdistrubusi normal dan homogen, maka dilakukan uji-t. Hasil uji-t menunjukkan bahwa nilai thitung pada pengetahuan faktual sebesar 2,31 dengan ttabel 2,01. Dapat disimpulkan bahwa terdapat pengaruh penggunaan model pembelajaran learning cycle $5 \mathrm{E}$ berbantuan Mind map terhadap pengetahuan faktual dan konseptual pada pembelajaran IPA.

\section{Pengetahuan Konseptual}

Nilai rata-rata posttest pengetahuan faktual pada pembelajaran IPA dikelas eksperimen yaitu 90, sedangkan pada kelas kontrol nilai pengetahuan faktual 90 . Nilai rata-rata posttest kelas eksperimen pengetahuan faktual 84,36, sedangkan 
pada kelas kontrol, nlai rata-rata pengetahuan faktual 73,59. Hasil pretest menunjukkan nilai rata-rata pada kelas eksperimen lebih besar daripada kelas kontrol. Setelah melakukan perhitungan rata-rata, selanjutnya dilakukan uji normalitas. Pengujian normalitas menggunakan rumus chi-kuadrat. Data dikatakan normal jika penghitungan diperoleh nilai x2hitung $<$ x2tabel. Pada kelas eksperimen diperoleh nilai $x_{2}$ hitung pada pengetahuan konseptual sebesar 3,02 dan padakelas kontrol sebesar 5,98 dengan x2tabel sebesar 11,07 artinya x2hitung $<$ x2tabel. Hasil tersebut memberikan indikasi bahwa hasil pretest kelas eksperimen dan kelas kontrol berdistribusi normal. Setelah melakukan uji normalitas, selanjutnya dilakukan uji homogenitas menggunakan uji-F. Hasil pretest menunjukkan bahwa nilai Fhitung pengetahuan konseptual sebesar 1,59 dengan Ftabel sebesar 1,95 artinya status varian pretest kelas eksperimen dan kelas kontrol berasal dari varian yang homogen. Pengujian selanjutnya yaitu uji hipotesis dengan uji-t. hasil uji-t menunjukkanbahwa nilai thitung pengetahuan konseptual sebesar 0,78 lebih kecil daripada ttabel sebesar 2,01. Sehingga dapat disimpulkan bahwa tidak terdapat pengaruh signifikan pada siswa kelas eksperimen dan kelas kontrol.

Hasil posttest menunjukkan nilai rata-rata pada kelas eksperimen lebih besar daripada kelas kontrol. Setelah melakukan penghitungan rata-rata, selanjutnya dilakukan uji normalitas menggunakan rumus chi kuadrat. Pada kelas eksperimen, $\mathrm{x}_{2}$ hitung pengetahuan konseptual sebesar 2,02 dan kelas kontrol 3,39 dengan x2tabel sebesar 11,07, artinya $\mathrm{x}$ 2hitung<x2tabel. Hasil tersebut memberikan indikasi bahwa posttest kelas eksperimen dan kelas kontrol berdistribusi normal. Selanjutnya dilakukan uji homogenitas menggunakan uji F. Hasil $\mathrm{F}_{\text {hitung posttest }}$ pengetahuan konseptual sebesar 1,07 dengan $F_{\text {tabel }}$ sebesar 1,95 artinya status varian hasil posttest kelas eksperimen dan kelas kontrol berasal dari varian yang homogen. Karena kedua sampel berdistrubusi normal dan homogen, maka dilakukan uji-t. Hasil uji-t menunjukkan bahwa nilai thitung pengetahuan konseptual 3,30 dengan ttabel 2,01. Dapat disimpulkan bahwa thitung $>$ tabel maka H0 ditolak atau terdapat pengaruh penggunaan model pembelajaran learning cycle $5 \mathrm{E}$ berbantuan Mind map terhadap pengetahuan faktual dan konseptual pada pembelajaran IPA.

Nilai rata-rata pretest dan posttest pengetahuan faktual dan konseptual pada pembelajaran IPA kelas eksperimen dan kelas kontrol disajikan pada diagram 1 berikut ini.

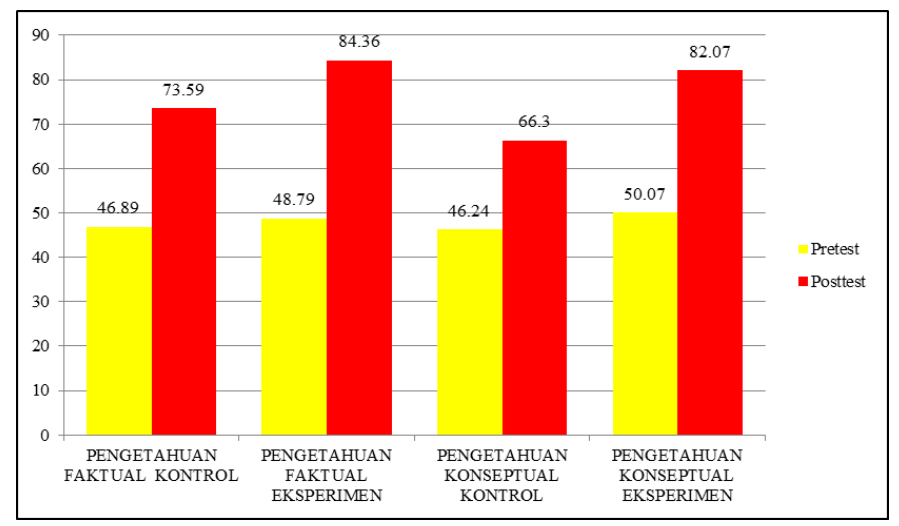

Diagram 1. Nilai rata-rata posttest pengetahuan faktual dan konseptual

\section{PEMBAHASAN}

\section{Kualitas Karya Mind map}


Tahap pertama pada model learning cycle $5 \mathrm{E}$ yaitu engagement, siswa ditunjuk secara acak untuk menceritakan pengalamannya yang berkaitan dengan panas dan perpindahannya dalam kehidupan sehari-hari. Selanjutnya, guru memfokuskan perhatian siswa untuk melihat tayangan slide dan video materi panas dan perpindahannya. Selesai menonoton, guru dan siswa bertanya jawab mengenai konsep perpindahan panas. Pada tahap ini pula guru dapat mengetahui kemampuan awal siswa melalui lembar kerja peserta didik 1, dimana siswa ditugaskan untuk membuat mind map dari apa yang mereka ketahui. Tahap engagement akan dibantu dengan pembuatan mind map agar siap dalam fase penyelidikan. Hal ini sesuai berdasarkan penelitian Nida, dkk (2017), bahwa mind map yang dibuat pada tahap engagement digunakan untuk mempersiapkan siswa dalam pembelajaran pada tahap eksploration dan eksplanation. Siswa sangat bersemangat membuat mind map yang berwarna-warni dan berbeda-beda bentuk.

Tahap kedua yaitu eksploration (eksplorasi), siswa mengerjakan Lembar kerja peserta didik 2 (LKPD 2) untuk mencari data guna memecahkan masalah dan memperkuat konsep pada fase engagement. Selama kegiatan eksplorasi, siswa akan terbantu dengan mind map yang dibuat di awal pembelajaran karena menjadikan siswa fokus pada tujuan percobaan yang nantinya dapat pula ditambahkan sebagai cabang pada mind map. Mind map dapat membantu siswa dalam mengasimilasi informasi baru dan mengembangkan skema konseptual untuk memecahkan masalah melalui percobaan (Balim, 2013:351).

Tahap ketiga yaitu eksplanation (menjelaskan), guru membimbing siswa berdiskusi kelas berdasarkan hasil dari tahap eksploration. Siswa diberi kesempatan untuk menjelaskan konsep dengan menjelaskan konsep dngan mempresentasikan hasil dari percobaan dan pengamatan yang dibantu dengan mind map untuk menjelaskan hasil temuan. Menurut Selvana (2017) menyatakan bahwa mind map membantu siswa untuk berpikir positif, membangun hubungan antar siswa dan guru, dan mengintegrasikan pembelajaran. Pada pelaksanaannya, guru perlu membimbing jalannya diskusi, menguatkan, dan meluruskan konsep.

Tahap keempat yaitu elaboration (pengembangan), guru memimpin diskusi kelas untuk meluruskan konsep untuk menuntun siswa mengaplikasikan konsep yang dimilikinya dengan menganalisis dan melengkapi bagian rumpang mind map sesuai arahan guru. Hal ini sejalan menurut Buzan (2012) bahwa mind map dapat memberi pandangan menyeluruh pokok permasalahan, mengumpulkan data dan mendorong pemecahan masalah. Mind map yang telah selesai dapat digunakan pada tahap evaluation.

Tahap kelima pada fase learning cycle 5E yaitu evaluation (evaluasi). Pada tahap ini diberikan evaluasi pengetahuan siswa dengan cara guru menunjuk secara acak siswa untuk melakukan tanya ajwab hasil mind map yang dibuatnya. Pada tahap ini siswa untuk dapat menyimpulkan kegiatan selama pembelajaran. Menurut Bilgin et. al.(2013:594) menjelaskan bahwa mind map dapat digunakan untuk mengevaluasi struktur berpikir siswa terhadap hubungan antar konsep materi.

Pemaduan mind map pada setiap langkah model pembelajaran learning cycle $5 \mathrm{E}$ akan membuat siswa terlibat aktif pada setiap tahapan dalam pembelajaran. Buzan (2012) menjelaskan bahwa mind map dapat membantu siswa dalam kegiatan merencanakan, mengkomunikasikan, menyelesaikan masalah, dan mengevaluasi secara keseluruhan.

Secara keseluruhan hasil karya mind map dibuat pada saat tahap engagement dengan masing-masing siswa sudah membuat 2 cabang dari cabang utama dengan kata kunci lebih dari 3, selanjutnya pada tahap eksploration, elaboration siswa 
hanya menambahkan paling banyak 2 cabang unutk melengkapi mind map. Sedangkan ada tahap eksplanation, siswa menggunkan mind map untuk presentasi didepan kelas. Hasil karya mind map dinilai menggunakan rubrik penilaian dengan tiga kriteria dan rentang skor 1-4. Nilai tertinggi yaitu 83,33 dan nilai terendah adalah 41,66. Siswa dengan nilai hasil mind mapnya tinggi banyak menggunakan cabang dan kata kunci ketika membuat mind map. Sedangkan secara keseluruhan karya mind map kurang pada penilaian kriteria 3 yaitu warna dan desain pada tiap-tiap cabang mind map yang dibuat.

\section{Pengetahuan Faktual}

Pada tahap pertama engagement learning cycle 5E membantu siswa membangkitkan minat belajar dengan memfasilitasi siswa untuk mengumpulkan fakta-fakta melalui sajian video, gambar, contoh mind map yang menarik dan mudah dimengerti. Sejalan menurut Putriani (2016:9) bahwa untuk memotivasi siswa, guru dapat mengajukan pertanyaan-pertanyaan tentang proses faktual dalam kehidupan sehari-hari. Selain itu pada tahap engagement, guru dapat melihat pengetahuan awal siswa berdasarkan tanya jawab dan hasil awal karya mind map materi yang telah siswa buat sebagai pertimbangan guru untuk menentukan proses pembelajaran dengan tepat. Hal ini disampaikan oleh Menurut Snadar (2011), bahwa guru perlu mengetahui pengetahuan awal siswa untuk membantu dalam memahami atau mengidentifikasi masalah-masalah yang mereka hadapi.

Pada tahap eksploration, siswa diberi kesempatan untuk berdiskusi dalam kelompok-kelompok untuk melakukan percobaan dan pengamatan yang dapat meningkatkan pengetahuan faktual siswa karena siswa melakukan sendiri menggunakan seluruh indra yang dimilikinya untuk terlibat. hal ini sejalan menurut Dewi, dkk (2018:118) bahwa tahapan eksploration memberi siswa kesempatan untuk melakukan dan mencatat pengamatan melalui paktikum. Selain itu menurut Putriani, dkk (2016:9) bahwa dalam diskusi kelompok, siswa akan saling bertukar pikiran satu sama lain tentang kemungkinan fakta dan pembuktian untuk memcahkan masalah. Hasil praktikum dapat ditambahkan sebagai kata kunci pada cabang min map untuk mudah diingat oleh siswa.

Tahap ketiga yaitu eksplanation atau penjelasan, pada tahap ini siswa menggunakan mind map sebagai bantuan untuk menjelaskan hasil pengerjaan LKPD. Pada tahapan ini siswa dituntut untuk menghubungkan seluruh fakta-fakta yang dimiliki untuk dijadikan satu menjadi sebuah konsep yang utuh. Hal ini sejalan menurut Dewi, dkk (2018:118) bahwa siswa memberikan bukti dan klarifikasi berdasarkan apa yang dijelaskan. Tahap keempat yaitu elaboration atau pengembangan konsep dengan memperdalam pengetahuan faktual dengan pelurusan konsep sesuai materi dan penambahana cabang pada mind map. Hal ini sejalan menurut Nida,dkk (2017:8) bahwa elaboration melatih siswa mencari hubungan sebab dan akibat. Tahap kelima yaitu evaluation, dimana siswa secara acak ditunjuk untuk menjawab pertanyaan dari guru tentang materi yang seharusnya dibuat dalam mind map dan mengerjakan soal postest.

Berdasarkan uraian diatas dapat disimpulkan bahwa peningkatan nilai pengetahuan faktual siswa yang dibelajarkan dengan model pembelajaran disebabkan karena siswa diberi kesempatan untuk menggali pengetahuan faktual serta proses pembelajaran yang menekankan pada siswa melakukan sendiri.. Selain itu setiap tahapan dibantu dengan mind map untuk mengenali apa itu mind map, presentasi, sampai evaluasi. Dengan model pembelajaran siklus belajar berbantuan mind map siswa terlibat aktif dalam pembelajaran sehingga lebih paham materi yang dipelajari, terbukti dari peningkatan nilai pengetahuan faktual.

Hasil penelitian ini sama dengan hasil penelitian Setiawan, (2017), bahwa hasil pembelajaran LC $5 \mathrm{E}$ berbantuan mind map lebih tinggi, hal ini dikarenakan LC $5 \mathrm{E}$ berbantuan mind map fokus pada aktivitas belajar siswa dan guru sebagai 
Nalansari, I. F., Winarni, E.W., Agusdianita, N.

fasilitator setiap kegiatan. Hal ini agar ya tercapai kompetensi-kompetensi yang harus dicapai dalam proses pembelajaran.

\section{Pengetahuan Konseptual}

Pada tahap engagement atau pembangkitan minat, siswa dituntut untuk dapat membaca dan menggali gejala-gejala dan fakta yang ada dilingkungan untuk dijadikan sebuah konsep yang utuh berdasarkan pengetahuan awal melalui proses pengamatan sumber belajar, maupun tanya jawab. Menurut Veronika (2011) fase engagement berfungsi untuk menggali pengetahuan guru perlu mengetahuai pengetahuan awal siswa untuk dikaitkan dengan konsep yang akan dipelajari. Hal sama pada penelitian Nida, dkk (2017) bahwa fase ini akan dapat mengkonstruksi pengetahuan kognitif siswa sehingga dapat mengembangkan konsep yang didapat pada saat eksplorasi. Pada tahap ini siswa akan membuat mind map dengan petunjuk dalam LKPD 1.

Tahap kedua yaitu eksploration (eksplorasi), Pada tahap ini siswa akan melakukan 3 percobaan untuk menemukan konsep panas dan perpindahan panas. Percobaan pertama yaitu memanaskan sendok diatas lilin, percobaan kedua adalah mendekatkan telapak tangan pada api lilin, dan percobaan ketiga adalah memanaskan air yang dicampur dengan serbuk gergaji. Tahap ini siswa diberi kesempatan membangun konsep yang dipikirkan berdasarkan percobaan dan pengamatan mengenai konsep panas dan perpindahannya yang dilakukan untuk menjawab pertanyaan-pertanyaan di LKPD secara kelompok. Pada tahap ini pada tahap ini siswa diminta untuk memikirkan konsep dan jawaban di LKPD dengan pengamatan dan literatur. LKPD yang dibagikan kepada siswa berisi petunjuk untuk melaksanakan praktikum dan soal berdasarkan pengamatan. LKPD berisi arahan untuk membimbing siswa dalam mengkosntruk pengetahuannya. Menurut pandangan konstruktivisme bahwa keterlibatan aktif siswa dalam mengkonstruksi pemahamannya. Menurut penelitian Bahriah,(2014), yang menyatakan bahwa belajar kelompok membantu pemecahan masalah.

Tahap ketiga yaitu eksplanation (penjelasan), Pada tahap ini siswa harus menguasai konsep yang diperoleh sehingga dapat menyampaikan dengan baik dan benar menggunakan kalimat siswa sendiri. Menurut hasil penelitian Dewi, dkk (2018:118) bahwa siswa harus didorong menjelaskan konsep dengan kalimat mereka sendiri. Pada pelaksanaan pembelajaran, tahap eksplanasi dilaksanakan dalam bentuk diskusi kelas dimana masing-masing kelompok maju ke depan kelas untuk menyampaikan pendapat dan hasil pengerjaan LKPD2 dengan bantuan mind map untuk menghubungkan konsep-konsep terkait. Kelompok lain diharapkan dapat menyimak, mencatat, dan mencocokkan jawaban untuk nantinya aka nada kesimpulan hasil diskusi kelas yang telah dilaksanakan.

Tahap keempat adalah elaboration (pengembangan), Kegiatan pada tahap ini berguna untuk membantu siswa menguasai dan mengorganisasi pengetahuan. Siswa akan diperlihatkan karya mind map yang lengkap sesuai materi pembelajaran beserta penjelasan dari guru untuk meluruskan konsep dan menghindari adanya miskonsepsi pada tahap-tahap sebelumnya. Hasil penelitian Veronika (2017) bahwa pada tahap ini guru membahas permasalahn dan menekankan pada pada konsep-konsep yang akan memperjelas miskonsepsi yang terjadi pada siswa. Pada tahap ini siswa dapat menambahkan cabang pada bagian mind map yang belum memuat kata kunci penting dalam materi pembelajaran.

Tahap kelima yaitu evaluation (evaluasi), siswa ditunjuk secara acak untuk menjawab pertanyaan guru mengenai konsep-konsep materi pembelajaran. Selain itu, siswa juga mengerjakan soal pengetahuan faktual dan konseptual masing- 
masing 10 soal. Tahap ini berfungsi untuk melihat hasil dari pembelajaran yang telah dilakukan. Menurut hasil penelitian Nida, dkk (2016:8), fase ini siswa dituntut untuk menyimpulkan hasil selama pembelajaran dengan menjawab soal yang diberikan.

Langkah-langkah learning cycle $5 \mathrm{E}$ berbantuan mind map memungkinkan siswa menghubungkan pengetahuan yang telah dimiliki dengan pengetahuan baru yang akan dipelajari dengan cara mengenali, mengeksplorasi, menjelaskan, mengembangkan konsep yang didapat, dan selanjutnya mengevaluasi pemahaman pengetahuan baru yang didapat. Dalam pelaksanaan pembelahjaran, guru hanya berperan membimbing dna memberikan arahan untuk mengkonstruksi pengetahuan siswa.

\section{Simpulan}

Kualitas mind map berbeda-beda antar siswa satu dengan siswa lain. Hasil penilaian mind map menunjukkan bahwa siswa telah mampu membuat mind map dengan banyak cabang dan kata kunci namun kurang pada desain dan warna. Nilai tertinggi yaitu 83,33 dan nilai terendah 41,66. Hasil pengetahuan faktual thitung $>$ tabel yaitu 2,31>2,01. Maka $\mathrm{H}_{0}$ ditolak atau terdapat pengaruh yang signifikan setelah siswa melakukan pembelajaran dengan model learning cycle 5E berbantuan Mind map. Mind map membantu siswa aktif dalam pembelajaran sehingga meningkatkan nilai pengetahuan faktual. Hasil thitung $>$ tabel pengetahuan konseptual yaitu $3,30>2,01$. Maka $\mathrm{H}_{0}$ ditolak atau terdapat pengaruh yang signifikan setelah siswa melakukan pembelajaran dengan model learning cycle 5E berbantuan Mind map terhadap pengetahuan konseptual.

\section{Saran}

Bagi siswa, pembelajaran learning cycle $5 \mathrm{E}$ berbantuan mind map karena dapat meningkatkan pengetahuan faktual dan konseptual siswa, mengaktifkan siswa selama pembelajaran, mengkonstruksi pemahaman, meningkatkan sikap ilmiah dan menyenangkan bagi siswa dengan berkreatifitas membuat mind map. Bagi guru, berdasarkan penelitian yang dilakukan siswa banyak menghabiskan waktu pada kegiatan percobaan dan pengamatan tahap eksploration. Selanjutnya untuk dapat dipilih materi dengan percobaan yang lebih sedikit dan sederhana untuk dilakukan oleh siswa sekolah dasar dan perlu pengaturan kelas untuk suasana yang nyaman. Bagi peneliti lain, disarankan untuk menggunakan model pembelajaran learning cycle $5 \mathrm{E}$ berbantuan mind map tidak hanya dalam pembelajaran IPA, namun pada pembelajaran tematik maupun mata pelajaran lain. Pada saat pelaksanaan pembelajaran learning cycle berbantaun mind map, penyampain perintah pembuatan mind map harus jelas dan dipahami oleh siswa pada setiap komponen yang akan dibuat baik itu pembuatan cabang, kata kunci, dan pewarnaan atau desain.

\section{Referensi}

Balim, A.G., (2013). Use Of Technology Assisted Techniques Of Mind mapping And Concept Mapping In Science Education. A construktivist Study. Irish Education Studies, 32(4): 437-456. Diunduh pada maret 2020.

Bahriah, E.S., Sofyatiningrum, E., Irawadi, D., (2014). Peningkatan Penguasaan Konsep Kesetimbangan Kimia Dengan Pendekatan Inkuiri Terintegrasi Nilai. Jurnal UDUSAINS. Vol. 6, No. 2, Hal:178-184.

Bilgin, I, Coscun, H \& Aktas, 1., (2013). The Effect Of 5E Learning cycle On Mental Ability Of Elementary Student. Jurnal of Baltic Science Education, 12 (5) 592607.

Buzan, T., (2012), Buku Pintar Mind map. Jakarta: PT. Gramedia Pustaka Utama. 
Cahyarini, A., Rahayu, S., Yahmin. (2016). Pengaruh Model Pembelajaran Learning cycle 5E Terhadap Penguasaan Konsep Siswa Pada Materi Asam Basa. Prosiding Seminar Nasional II Kerjasama Prodi Pendidikan Biologi FKIP dengan Pusat Studi Lingkungan Dan Kependudukan (PSLK) Universitas Muhammadiyah Malang.

Dewi, N.P.S., Ardana, I.K., Putra .M., (2018). Pengaruh Model Pembelajaran Learning cycle $5 \mathrm{E}$ Berbantuan Media Lingkungan Terhadap Kompetensi Pengetahuan Ipa. Jurnal Penelitian dan Pengembangan Pendidikan. Vol. 2 (2) pp. 113-120.

Nida, S., Mahanal, S., Pradana D., (2017), Keefektifan Model Learning cycle 5E Dipadu Teknik Mind mapping Untuk Meningkatkan Keterampilan Proses Sains Siswa Smp. Pancasakti Science Education Journal PSEJ 2 (1) (2017) 1-1 http://e-journal.ups.ac.id/index.php/psej. Diunduh pada oktober 2019.

Putriani., N.K.D., Murda, I.N., Rati, N.W.,(2016). Pengaruh Model Pembelajaran Learning cycle 5E Berbantuan Media Grafis Terhadap Hasil Belajar IPA Pada Siswa Kelas Iv. e-Journal PGSD Universitas Pendidikan Ganesha Jurusan PGSD Vol: 4 No: 1.

Selvana, D., (2017). Pengaruh Media Mind mapping Terhadap Penguasaan Konsep Dan Habits Of Mind Siswa Kelas VII Pada Mata Pelajaran Biologi Di SMP Negeri 19 Bandar Lampung. SKRIPSI

Setiawan, I W.P., Suartama, I. K., Putri, D.W.A.M., (2017). Pengaruh Model Pembelajaran Learning cycle 5E Berbantuan Mind mapping Terhadap Hasil Belajar Matematika. e-Journal PGSD Universitas Pendidikan Ganesha $\begin{array}{lllll}\text { Mimbar } & \text { PGSD } & \text { Vol: } & 5 & \text { No: }\end{array}$ https://ejournal.undiksha.ac.id/index.php/JJPGSD/article/view/10841. Diunduh Pada Oktober 2019.

Siswati \& Mei L.W. (2015), Pengaruh Metode Mind map Terhadap Peningkatan Hasil Belajar Mata Pelajaran Ilmu Pengetahuanalam Terpadu Pada Siswa Kelas VII. Jurnal Empati, Oktober 2015, Volume 4(4), 131-138. https://media.neliti.com/media/publications/70398-ID-none.pdf. Diunduh pada Januari 2020.

Snadar, E., (2011). Using The 5E Learning cycle Of Science Education To Teach Information Skills. Indian Libraries. Vol 30, No.2, Hal:21-23.

Veronika. T., (2017), Pengaruh Model Pembelajaran Learning cycle 5E Terhadap Penguasaan Konsep Sistem Peredaran Darah Manusia Kelas VIII SMP Negeri 19 Palembang. SKRIPSI

Zulchaidar, I., (2017), Penerapan Model Learning cycle 5E Untuk Meningkatkan Prestasi Belajar Siswa Smp Dalam Pembelajaran IPA. Jurnal Penelitian $\begin{array}{llllll}\text { Pendidikan } & \text { Vol. } & 34 & \text { Nomor } & 2 & \text { Tahun } \\ 2017 .\end{array}$ https://journal.unnes.ac.id/nju/index.php/JPP/article/download/10798/137-144. diunduh pada 19 Desember 2019 